\title{
What Leads Subjective Well-Being to Change Throughout Adolescence? An Exploration of Potential Factors
}

\author{
Mònica González-Carrasco ${ }^{1}$ - Ferran Casas $^{1}$. \\ Ferran Viñas $^{1} \cdot$ Sara Malo $^{1} \cdot$ M. Eugènia Gras ${ }^{1}$. \\ Lívia Bedin ${ }^{2}$
}

Accepted: 22 December 2015 / Published online: 20 January 2016

(C) Springer Science+Business Media Dordrecht 2016

\begin{abstract}
This article presents the results of a one-year follow-up study on a sample of 940 adolescents, in which participants have been classified according to the changes they have experienced in their subjective well-being (SWB), measured by means of two different single-item scales (overall life satisfaction -OLS- and happiness overall HOL). A range of multinomial logistic regression models were employed to determine which factors lead to such differences. Results show that when OLS is considered, the factor most contributing to an increase in SWB is family self-concept, while the one most contributing to its decrease is satisfaction with the family. When HOL is taken as the dependent variable, the most important factor in predicting an increase in SWB is being valued in the future according to the amount of money I have, with life optimism being the most important factor in predicting its decrease. Only three indicators (the importance of being valued in the future according to the amount of money I have, feeling happy at home and satisfaction with myself) contribute to explaining both boys' and girls' models when OLS is taken as the dependent variable, while only one indicator (satisfaction with standard of living) is shared in both boys' and girls' models when HOL is the dependent variable. The resulting implications for adolescent SWB are discussed.
\end{abstract}

Keywords Subjective well-being · Adolescence - Multinomial logistic regression · Longitudinal study

Mònica González-Carrasco

monica.gonzalez@udg.edu

1 Faculty of Education and Psychology, Quality of Life Research Institute, University of Girona, Pl. St. Domènec, 9, 17071 Girona, Spain

2 Institute of Psychology, Federal University of Rio Grande do Su, Rio Grande do Su, Brazil 


\section{Introduction}

\subsection{Subjective Well-Being}

According to Ben-Arieh et al. (2014), research into children's well-being cannot be separated from the consideration of children's perceptions, evaluations, and aspirations regarding their own lives, this including their subjective well-being (SWB). SWB refers to how people evaluate their lives, both generally and for specific domains (family, friends, leisure time, etc.). This definition is equally applicable to adults and adolescents (Ben-Arieh et al. 2014).

There is widespread agreement that SWB is composed of three elements which reflect the combination of one cognitive process (satisfaction/dissatisfaction) and two affective processes (positive and negative affect) (Cummins and Cahill 2000). These elements are: 1) judgments regarding life satisfaction (overall and for specific domains); 2) the presence of positive affect; and 3) the absence of negative affect (Argyle 1993; Diener 1994). A controversial debate has long existed on which of the two components, cognitive (satisfaction) or affective (happiness), has a stronger impact on SWB. This is known as the happiness (represented by Bradburn 1969) versus the satisfaction (represented by Cantril 1965) approach. Campbell et al. (1976) considered that both constructs are necessary for understanding SWB and suggested including single-item scales on both constructs in any research on SWB, although more recent studies place a stronger emphasis on the affective component (Davern et al. 2007). Further research is needed far beyond adult samples.

In this paper, besides considering SWB as both an affective and cognitive construct, we also assume that it represents a point of convergence between the hedonic and eudaimonic approaches (see Ryan and Deci 2001, for a more detailed description of the two traditions within well-being studies). Consequently, our focus is not only on measuring its hedonic components, such as affects, life satisfaction and happiness, but also on other SWB-related factors, such as values aspired to, which are much more related to a eudaimonic conception of SWB, defined in terms of the person as being fully functioning rather than as simple attending desires (Ryan and Deci 2001).

\subsection{Age and Subjective Well-Being}

Different cross-sectional studies have reported a progressive decrease in levels of SWB from early to late adolescence (Petito and Cummins 2000; Ullman and Tatar 2001; Bradford et al. 2002; Park 2005; Baltatescu 2006; Casas et al. 2007a; Goldbeck et al. 2007; Tomyn and Cummins 2011b; Casas et al. 2012a; Currie et al. 2012; Chui and Wong 2015; Liu et al. 2015; Singh et al. 2015). However, as they have not followed the same adolescents over a specific period of time, it is not possible to know to what extent SWB changes. This knowledge could be of help, for instance, in developing actions to prevent a decrease in SWB levels outside normative ranges.

Longitudinal studies carried out on adolescents are generally not so much focused on adolescents' but rather adults' SWB as explained through early life experiences (see, for instance, Olsson et al. 2013) or on the connection between SWB and family relationships, specifically parental support (Saha et al. 2010). An exception to this is 
the work by González-Carrasco et al. (2016), which observed a progressive longitudinal and cross-sectional decline in a sample of adolescents' SWB aged mostly from 10 to 15 , beginning at the age of 11-12.

The results obtained were interpreted by the authors as the consequence of restructuring the Homeostatically Protected Mood (HPM), proposed by Cummins (2010), within this age range and triggered by developmental factors, which then result in a decrease in SWB levels. The aforementioned model makes use of the analogy of maintaining body temperature and considers SWB to be actively controlled and maintained to ensure a positive sense of well-being (Cummins 2013). The purpose of homeostasis is to defend the affective core of SWB, which is considered to be a stable, genetically endowed, positive mood (Davern et al. 2007), protected by both external and internal buffers.

The study by González-Carrasco et al. (2016) does not explain, however, what causes the differences between those adolescents experiencing a decrease in their SWB (the highest percentage), those experiencing an increase and those whose SWB remains the same for the first to the second year of data collection. This article is an attempt to narrow this gap.

\subsection{Gender and Subjective Well-Being}

SWB differences between the genders have been reported in the case of adolescents with regard to specific life domains rather than general SWB. For instance, Casas et al. (2007b) found that 12 to 16-year-old girls obtain higher scores in learning-related satisfaction than boys of the same ages, while boys score higher in satisfaction with physical activities. Another example is found in a cross-sectional study on a sample recruited in Hong Kong $(N=1428)$ by Chui and Wong (2015), who reported that higher academic satisfaction is associated with greater happiness in boys and greater satisfaction with life in girls. These authors also observed that the boys in their sample became less happy as they entered late adolescence, while the effect of age was not significant in the case of girls.

In the aforementioned study by González-Carrasco et al. (2016), the decline in SWB levels was more pronounced among girls. This observation was interpreted as the girls' homeostatic system more likely to be sensitive to external variations. Further research is needed to determine the impact various factors may have on boys and girls separately, which could explain the differences in their SWB levels over time. This knowledge would help determine to what extent programs aimed at promoting SWB should take into account the gender of participants and therefore offer personalized actions according to this socio-demographic variable.

\subsection{Measuring Instruments and Subjective Well-Being}

Some instruments have been developed for assessing SWB specifically in children and adolescents (for instance, Seligson, Huebner and Valois' Brief Multidimensional Student's Life Satisfaction Scale, BMSLSS), while others initially developed for adults have been successfully applied to adolescents samples (Holte et al. 2014), among them, Cummins, Eckersley, van Pallant, Vugt and Misajon's Personal Well-Being Index (PWI). One of the most frequently used scales with adolescents is overall life satisfaction (OLS), which was first used in adult samples. 
The OLS and the happiness with overall life scale (HOL) are single-item, contextfree scales, while the BMSLSS and the PWI are multiple-item domain-based scales, that is, grounded on the assumption that SWB is comprised of different life domains (Holte et al. 2014). Previous research on adolescent populations indicates that different results are obtained when different instruments are used to measure their SWB (see Casas et al. 2012a). In the work by González-Carrasco et al. (2016), it was observed that the change in SWB over a one-year period was more clearly observed through multi-item domain-based scales than single-item. This result was interpreted as the changes occurring at the beginning of adolescence and later probably not being sufficiently strong to affect overall SWB evaluations, even if they affect specific domains.

In this article, two single-item scales will also be compared (OLS and HOL), taking into account the extent to which various SWB-related factors may contribute differently to the two scales, while including different life satisfaction domains. This comparison will allow us to determine to what extent changes in the cognitive and affective components of SWB are or are not predicted by the same factors.

\subsection{Subjective Well-Being Related Factors}

The literature highlights many factors closely related to adolescents' SWB. Among them are social support, self-esteem, perception of control, relationships with the family, relationships with peers, school performance, self-efficacy and personality traits, including optimism (Leung et al. 2004; Suldo and Huebner 2006; Gilman and Huebner 2006; Antaramian et al. 2008; Garcia 2011; Malo et al. 2011; Orejudo et al. 2012; Weber et al. 2013; Raboteg-Saric and Sakic 2014; Weber and Huebner 2015). In a recent international study, it was observed that the family, school and community lives of 12 year-old children from 11 different countries are important predictors of SWB after controlling for country-specific cultural and contextual factors (Lee and Yoo 2015).

Tomyn and Cummins (2011a) have also highlighted the importance of core affects when explaining adolescents' SWB. Core affects are defined as neurophysiological states which are consciously accessible as the simplest raw feelings evident in moods and emotions. More recently, it has been proposed that core affect may well be the heart of mood and emotion and not synonymous with them (Yik et al. 2011). According to the circumplex model (Russell 2003), affect self-ratings can be allocated in different octants formed by the confluence of various two-dimensional axes with opposite affects at each extreme. Positive-negative affect conforms to one of those axes and activationdeactivation to another.

The above results, however, are generally based on cross-sectional studies which do not help ascertain the extent to which these factors contribute to predicting SWB levels over time. This knowledge could be of help in promoting those factors that contribute most to increased SWB levels across time and reducing the impact of those factors most contributing to its decrease. In this respect, Lippman et al. (2011) consider it important to monitor and reduce negative indicators such as school failure as well as identifying and increasing positive indicators such as school engagement.

Taking all of the above considerations into account, the aim of this article is twofold: (1) to identify potential differences among participants according to their 
classification into three groups (those experiencing an increase in overall life satisfaction and happiness with life overall, those remaining the same, and those experiencing a decrease in the same variables), and (2) to examine gender and age differences. Although no previous study of the same characteristics has been identified, we hypothesize that important differences will appear in the factors predicting OLS and HOL in all three groups, while only limited similarities are expected to be found between boys' and girls' models. Differences by age, the result of diverse needs and expectations, are also to be expected.

This study is designed to answer the following research questions:

1) Will differences in the factors that contribute most to SWB be identified according to the changes experienced by participants in their levels of SWB from 1 year to the next?

2) Will differences in the factors that contribute most to SWB be detected according to age of participants?

3) Will boys and girls differ in which factors contribute most to their SWB?

4) Will differences be identified according to the instrument employed (OLS and HOL)?

\section{Method}

\subsection{Sample}

The sample included in this study belongs to a follow-up study carried out over two academic years (2011-12 and 2012-13). Fifteen schools that allowed us to follow up with their students were selected through a convenience sampling procedure covering the province of Girona (Catalonia, north-east Spain). In the Spanish education system, primary school is compulsory and lasts 6 years. Secondary school is divided into compulsory and non-compulsory stages, compulsory secondary education lasting 4 years. This study focuses on the final 2 years of primary school and the 4 years of compulsory secondary school. If a school did not offer primary and secondary levels simultaneously, we selected primary and secondary schools located in the same town or city or one nearby in order to guarantee that those students changing from primary to secondary school were not lost.

The sample is composed of 940 students, distributed into five different cohorts according to the school year in which they were enrolled at the beginning of the study. Each cohort comprises the same sub-sample of participants under study during 2 years. For this reason, students in the same cohort can be within a certain age range. For example, participants in the first cohort were enrolled in Year 5 of primary school for the first year and Year 6 of primary school for the second. They ranged from 9 to 11 years old for the first year of data collection and from 10 to 12 for the second.

Students enrolled in the same school year were born in the same year, with the exception of the very few who had repeated a year or years. Data collection took place during the months of October and November, the youngest students in each cohort were therefore close to their birthday at the time they responded to the questionnaire. In the first year, participants were aged between 9 and 16, with a mean of 12.02 $(\mathrm{sd}=1.50)$. Table 1 shows the age distribution by cohort. 
Table 1 Distribution of cohorts according to age (first year of data collection)

\begin{tabular}{|c|c|c|c|c|c|c|c|c|c|}
\hline & 9 & 10 & 11 & 12 & 13 & 14 & 15 & 16 & Total \\
\hline $1^{\text {st }}$ cohort & 27 & 144 & 6 & 0 & 0 & 0 & 0 & 0 & 177 \\
\hline $2^{\text {nd }}$ cohort & 0 & 16 & 134 & 4 & 0 & 0 & 0 & 0 & 154 \\
\hline $3^{\text {rd }}$ cohort & 0 & 0 & 27 & 192 & 10 & 0 & 0 & 0 & 229 \\
\hline $4^{\text {th }}$ cohort & 0 & 0 & 0 & 21 & 137 & 16 & 0 & 0 & 174 \\
\hline $5^{\text {th }}$ cohort & 0 & 0 & 0 & 0 & 30 & 154 & 21 & 1 & 206 \\
\hline Total & $27(2.9 \%)$ & $160(17 \%)$ & $167(17.8 \%)$ & $217(23.1 \%)$ & $177(18.8 \%)$ & $170(18.1 \%)$ & $21(2.2 \%)$ & $1(.1 \%)$ & 940 \\
\hline
\end{tabular}

Of the total, $44.1 \%$ (415) were boys and $55.9 \%$ (525) girls. Table 2 displays the gender and cohort distribution of the sample.

Of the 15 schools that collaborated with the study, $54.1 \%$ were state-funded and $45.9 \%$ private. They were located in urban ( $>10,000$ inhabitants, according to Spanish standards) and semi-urban settings (between 2000 and 10,000 inhabitants) in three different counties (Alt Empordà, Baix Empordà and Gironès) in the province of Girona (Catalonia, north-east Spain). Students came from different socioeconomic backgrounds.

\subsection{Instruments}

This study focuses on the three psychometric instruments plus a list of satisfaction with different life domains used to assess SWB and the five SWB-related instruments included in the questionnaire. They are the following:

\subsubsection{Single Item on Overall Life Satisfaction (OLS)}

The importance of including a single-item scale on overall life satisfaction when studying SWB has been highlighted by Campbell et al. (1976). In our research, we included a question on satisfaction with your overall life, using an end-labelled 0-10 scale from totally dissatisfied to totally satisfied.

Table 2 Distribution of sample by gender and cohort

\begin{tabular}{llll}
\hline & Boy & Girl & Total \\
\hline $1^{\text {st }}$ cohort & $74(17.8 \%)$ & $103(19.6 \%)$ & 177 \\
$2^{\text {nd }}$ cohort & $88(21.2 \%)$ & $66(12.6 \%)$ & 154 \\
$3^{\text {rd }}$ cohort & $93(22.4 \%)$ & $136(25.9 \%)$ & 229 \\
$4^{\text {th }}$ cohort & $69(16.6 \%)$ & $105(20 \%)$ & 174 \\
$5^{\text {th }}$ cohort & $91(21.9 \%)$ & $115(21.9 \%)$ & 206 \\
Total & $415(100 \%)$ & $525(100 \%)$ & 940 \\
\hline
\end{tabular}




\subsubsection{Single Item on Happiness Taking into Account Overall Life (HOL)}

Campbell et al. (1976) also pointed out the importance of including a single-item scale on happiness when studying SWB. In our research, we have included the following question: "Taking into account your overall life, would you say you are...?", offering options on a 0-10 scale from extremely unhappy to extremely happy. The HOL has proven to be a reliable and valid measure in community surveys (Abdel-Khalek 2006).

\subsubsection{Brief Multidimensional Student's Life Satisfaction Scale (BMSLSS)}

This scale was developed to be used with students aged 8-18. It includes five items referring to satisfaction with different life domains, plus one item on overall satisfaction. The psychometric properties of this scale have been published in different articles (Seligson et al. 2003; 2005; Huebner et al. 2006). Responses were originally encoded on a scale of $1-7$, from terrible to delighted. We have changed the $1-7$ scale to a $0-10$ scale in order to increase its sensitivity. Labels have been given to each value, describing satisfaction with each life domain from terrible to delighted. The overall item on life satisfaction was not considered in this article.

\subsubsection{Satisfaction with Different Life Domains}

A list of 18 life domains was explored. Five of them belong to the Personal Well-Being Index (Cummins et al. 2003): standard of living, health, relations with people, current and future security. The other domains explored were: yourself, things you have learned, relations with classmates, with teachers, the school/high school, father, mother, all the people living with you, with friends, neighbours, entertainment, own body and sports undertaken. A zero-to-ten scale was used, zero meaning "totally dissatisfied" and ten "totally satisfied".

\subsubsection{Self-Concept (AF-5)}

The original scale by García and Musitu (1999) has 30 items with 5 possible responses (1 meaning "never" and 5 "always"). In this study, 11 responses were allowed (0 meaning "never" and 10 "always"), following the recommendations of Cummins and Gullone (2000), who defend this type of scale given that it allows for finer nuances. Items refer to five components of self-concept: academic ("I am a good student"), social ("I have a lot of friends"), family ("I feel happy at home"), physical ("I am good at sports"), and emotional ("I am afraid of some things").

\subsubsection{Values Aspired to}

In order to explore the values adolescents aspire to, they were asked to what extent they would like to be appreciated for specific values on turning 21. A list of 10 values was explored: intelligence, professional status, family, "niceness" (friendliness), money, power, own image (appearance), popularity, kindness and relations with people. All were measured on a zero-to-ten scale, zero meaning "not at all" and ten "very much". Earlier research had already tested these values (see, for instance, Casas et al. 2007a). 


\subsubsection{Core Affects}

An 11-item scale based on Russell's (2003) Core Affect assessment was used. As this author proposed, affects from two dimensions were used: Pleasant-Unpleasant (six items, e.g., 'happy', 'sad') and Activated-Deactivated (five items, e.g., 'active', 'serene'). The participants were asked how "each of the following describes your feelings when you think about your life in general" on an 11-point scale from 0 ("not at all") to 10 ("very clearly").

\subsubsection{Social Support}

The family' and friends' sub-scales included by Vaux et al. (1986) in their Social Support Appraisals (SSA) were also administered. The two sub-scales together comprise 23 items which explore the perception that boys and girls have of the social support they receive from their family and friends. Scores range from 0 ("strongly disagree") to 10 ("strongly agree").

\subsubsection{Life Optimism}

We applied Scheier, Carver and Bridges' (1994) Life Orientation Test - Revised (LOT-R), a six-item scale developed to assess individual differences in generalized optimism versus pessimism. The scale ranges from 0 ("completely disagree") to 5 (“completely agree").

All the instruments were administered in Catalan, the official language used in Catalan schools. They had all been tested previously on different samples in this same language following pilot testing and a back-translation from the English or Spanish original, with the exception of the additional satisfaction with different life domains and values aspired to, which were originally formulated in Catalan (see, for instance, Malo et al. 2011; Casas et al. 2008; Casas et al. 2007a, b).

\subsection{Procedure}

The 15 schools willing to participate in the study were consulted regarding the most convenient dates for administering the questionnaire. Consent was previously requested from the parents or legal tutors of the students involved in the study. Once this was obtained, paper questionnaires were administered in the classroom setting twice over a year. Researchers were present during administration to clarify doubts and give instructions on how to complete the questionnaires. The students' regular teacher was also present to help researchers with classroom organization. Confidential treatment of the information provided by students was explicitly guaranteed, and they were informed that they were free not to participate.

\subsection{Analysis}

Linear regression models have been used on several occasions to study children's and adolescents' SWB in order to determine which factors contribute to explaining their SWB (see, for instance, the work by Holder and Klassen 2010; Suldo et al. 2015). 
However, these models are not so useful when the objective is to ascertain what differentiates children or adolescents according to their levels in a particular variable, logistic regression models being much more suitable to this end. Logistic regression models have already been used within SWB studies in order to compare, for instance, the self-reported responses of satisfied and dissatisfied adolescents with their overall lives in relation to different aspects such as support received from parents and other adults (Valois et al. 2009). As far as we know, they have not been applied to longitudinal studies assessing adolescents' SWB aimed at exploring the differences between those participants experiencing a decrease in their SWB and those reporting an increase or maintaining the same levels, this being an innovate aspect of this article.

Seven multinomial logistic regressions were performed, one for each of the separate instruments considered, taking changes in OLS levels from 1 year to the next as the dependent variable. The independent variables were: (a) satisfaction with different life domains, (b) the satisfaction domains included in the BMLSS, (c) values aspired to, (d) self-concept, (e) core affects, (f) social support, and (g) life optimism. Seven other multinomial logistic regression models were performed, following the same procedure, but in which the dependent variable was changes in HOL from 1 year to the next. In all cases, gender and cohort were included in the analysis. All independent variables included measurements from the first and second years of data collection. The total score was not considered in any of the scales.

Two final multinomial logistic regression models were calculated for the whole sample (one for OLS and the other for HOL) using only those items that appeared to be significant in the different partial models. Separate final models were calculated for boys and girls in order to identify potential differences between them.

Changes from 1 year to the next, for both OLS and HOL, were calculated by subtracting the scores obtained in the second year from those of the first and classifying them into three groups: an increase in OLS or HOL levels, a decrease in OLS or HOL levels, and no change (this meaning that the OLS and HOL scores were identical over the 2 years). In order to facilitate interpretation of the multinomial logistic regression models calculated, participants in the same group ("increase" or "decrease") were not differentiated by the amount of change they had experienced over a one-year period. For all the models calculated, the category of reference to which comparisons were made remained the same.

\section{Results}

\subsection{Overall Life Satisfaction (OLS)}

The highest percentage corresponds to those participants stating that their OLS has decreased over a one-year period, followed by those who have experienced no change (Table 3).

A logistic regression was performed, taking OLS as the dependent variable for each instrument, considered separately over the 2 years of data collection; gender and cohort were also included. The following items and constructs were included: (a) satisfaction with different life domains, (b) the satisfaction domains included in the BMLSS, (c) values aspired to, (d) self-concept, (e) core affects, (f) social support and (g) life optimism. Table 4 shows those items and constructs which are significant for each partial model. 
Table 3 Percentage of cases in which the OLS has increased, remained the same or decreased from the first to the second year of data collection

\begin{tabular}{llll}
\hline & \multicolumn{2}{l}{$\%$ of cases } & \\
\cline { 2 - 4 } & Boys & Girls & Total \\
\hline Increase & 21 & 21.9 & 21.5 \\
Remaining the same & 37.6 & 38.8 & 38.3 \\
Decrease & 41.5 & 39.2 & 40.2 \\
\hline
\end{tabular}

A final OLS model was performed, taking into account only those indicators included in Table 4. Participants' gender and cohort were also included in the analysis, since they were significant in some of the partial models. The model fit was adequate for the final model $\left(X_{90}^{2}=374.822, p<.001 ; \mathrm{R}^{2}\right.$ Nagelkerke $=.496$ ).

Globally, the final model correctly classifies a $65.5 \%$ of the cases $(51.9 \%$ for the increasing group, $70.7 \%$ for the no difference group and $67.6 \%$ for the decreasing group). Table 5 shows those items that are significant in the final model. Fourteen items contribute to explaining the increase in OLS scores. They belong to the instrument measuring values aspired to, self-concept, core affects, social support and life optimism. Five of the fourteen items refer to responses given in the first year of data collection and nine to responses given in the second year. Six of the fourteen items have a negative contribution, i.e., they help to reduce the likelihood of an increase in OLS. Nine items contribute to explaining the decrease in OLS scores, plus the fact of being a boy. The nine belong to the instrument measuring satisfaction with different life domains, the BMLSS, self-concept and life optimism. Five of the nine items refer to responses given in the first year of data collection and four to responses given in the second year. Five of them have a negative contribution, i.e., they help to reduce the likelihood of a decrease in OLS.

\subsection{Overall Life Satisfaction (OLS) and Gender}

The next stage was to calculate the final OLS model while considering boys and girls separately.

\subsubsection{Boys}

The highest percentage corresponds to those boys stating that their OLS has decreased over a one-year period, followed by those who have experienced no change (Table 3 ). The model fit was adequate for the final boys' model $\left(X^{2}{ }_{88}=382.764, p<.001 ; \mathrm{R}^{2}\right.$ Nagelkerke $=.605$ ).

Table 6 shows those items that are significant in the final model solely in the case of boys. Seven items contribute to explaining the increase in OLS scores. They belong to the instrument measuring values aspired to, self-concept, social support and life optimism. Two of the seven items refer to responses given in the first year of data collection and five to responses given in the second year. Four items have a negative contribution, i.e., they help to reduce the likelihood of an increase in OLS. Seven items contribute to explaining the decrease in OLS scores. They belong to the BMLSS, the 
Table 4 Indicators contributing to the increase/decrease of OLS included in the final logistic regression model (category of reference: remaining the same)

\begin{tabular}{|c|c|c|}
\hline & Increase & Decrease \\
\hline $\begin{array}{l}\text { Satisfaction with different } \\
\text { life domains }\end{array}$ & $\begin{array}{l}\text { Security for future (-) (1) } \\
\text { Own body (-) (1) } \\
\text { Sport undertaken (-) (1) } \\
\text { Own body (+) (2) }\end{array}$ & $\begin{array}{l}\text { Relations with other people (+) (1) } \\
\text { Standard of living (-) (2) } \\
\text { Relations with neighbours (-) (2) }\end{array}$ \\
\hline BMLSS & $\begin{array}{l}\text { Experience as a student (-) (1) } \\
\text { Myself (-) (1) }\end{array}$ & $\begin{array}{l}\text { Family (+) (1) } \\
\text { Myself (+) (1) } \\
\text { The place I live (+) (1) } \\
\text { Family (-) (2) } \\
\text { Myself (-) (2) }\end{array}$ \\
\hline Values aspired to & $\begin{array}{l}\text { Relations with other people (-) (1) } \\
\text { The money you have }(+)(2)\end{array}$ & Intelligence (-) (2) \\
\hline Self- concept & $\begin{array}{l}\text { I feel happy at home }(-)(1) \\
\text { I am very criticized at home }(+)(2) \\
\text { My friends appreciate me }(-)(2) \\
\text { I feel happy at home }(+)(2)\end{array}$ & $\begin{array}{l}\text { I am very criticized at home (-) (1) } \\
\text { My family would help me with any } \\
\text { kind of problem (+) (1) } \\
\text { I easily get scared (+) (1) } \\
\text { I feel happy at home (-) (2) } \\
\text { My family would help me with any } \\
\text { kind of problem (-) (2) } \\
\text { I am a good student (-) (2) } \\
\text { I am afraid of some things (+) (2) }\end{array}$ \\
\hline Core affects & & $\begin{array}{l}\text { Satisfied (+) (1) } \\
\text { Fortunate }(+)(1) \\
\text { Happy }(-)(2)\end{array}$ \\
\hline Social support & $\begin{array}{l}\text { My family holds a lot of affection } \\
\text { (love) for me }(+)(2) \\
\text { My friends care about my } \\
\text { well-being (-) (2) } \\
\text { My friends and I have done much } \\
\text { for each other (+) (2) }\end{array}$ & $\begin{array}{l}\text { My friends care about my well-being (-) (1) } \\
\text { My friends care about me (+) (1) } \\
\text { My family holds a lot of esteem for } \\
\text { me (+) (2) }\end{array}$ \\
\hline Life optimism & $\begin{array}{l}\text { I'm always optimistic about my } \\
\text { future (-) (1) } \\
\text { I hardly ever expect things to go } \\
\text { my way (+) (1) }\end{array}$ & $\begin{array}{l}\text { If something can go wrong for me, } \\
\text { it will }(+)(1) \\
\text { Overall, I expect more good things } \\
\text { to happen to me than bad }(+)(1) \\
\text { I'm always optimistic about my } \\
\text { future }(-)(2)\end{array}$ \\
\hline
\end{tabular}

(-) negative contribution / (+) positive contribution

(1) first year of data collection / (2) second year of data collection

instrument measuring self-concept, social support and life optimism. Four of the seven items refer to responses given in the first year of data collection and three to responses given in the second year. Four of them have a negative contribution, i.e., they help to reduce the likelihood of a decrease in OLS.

\subsubsection{Girls}

The highest percentage corresponds to those girls stating that their OLS has decreased over a one-year period, followed by those who have experienced no change (Table 3). 
Table 5 Regression on OLS for satisfaction with different life domains, the satisfaction domains of the BMLSS, self-concept, core affects, social support and life optimism, whole sample (category of reference: remaining the same)

\begin{tabular}{|c|c|c|c|c|c|}
\hline & Beta & $\mathrm{t}$ & $p$-value & O.R. & C.I. \\
\hline \multicolumn{6}{|l|}{ Increase (14 items) } \\
\hline Values aspired to: Money (2) & .146 & 10.551 & .001 & 1.157 & $1.060-1.263$ \\
\hline Self-concept: I feel happy at home (1) & -.410 & 11.934 & .001 & .664 & $.526-.838$ \\
\hline $\begin{array}{l}\text { Self-concept: My family would help me with any } \\
\text { kind of problem (1) }\end{array}$ & .394 & 10.965 & .001 & 1.483 & $1.174-1.873$ \\
\hline Self-concept: I am very criticized at home (2) & .100 & 4.625 & .032 & 1.105 & $1.009-1.211$ \\
\hline Self-concept: I feel happy at home (2) & .361 & 6.637 & .010 & 1.434 & $1.090-1.887$ \\
\hline $\begin{array}{l}\text { Self-concept: My family would help me with any } \\
\text { kind of problem (2) }\end{array}$ & -.345 & 7.030 & .008 & .709 & $.549-.914$ \\
\hline Self-concept: I am afraid of some things (2) & -.112 & 4.021 & .045 & .894 & $.801-.997$ \\
\hline Core affects: Satisfied (1) & -.177 & 4.403 & .036 & .837 & $.709-.988$ \\
\hline Core affects: Happy (2) & .420 & 7.249 & .007 & 1.523 & $1.121-2.068$ \\
\hline Social support: My friends care about me (1) & .202 & 4.175 & .041 & 1.224 & $1.008-1.487$ \\
\hline $\begin{array}{l}\text { Social support: My family holds a lot of affection } \\
\text { (love) for me ( } 2 \text { ) }\end{array}$ & .340 & 5.639 & .018 & 1.405 & $1.061-1.861$ \\
\hline $\begin{array}{l}\text { Social support: My friends care about my } \\
\text { well-being ( } 2 \text { ) }\end{array}$ & -.251 & 9.333 & .002 & .778 & $.663-.914$ \\
\hline $\begin{array}{l}\text { Social support: My friend and I have done much } \\
\text { for each other ( } 2)\end{array}$ & .301 & 7.494 & .006 & 1.351 & $1.089-1.676$ \\
\hline $\begin{array}{l}\text { Life optimism: I'm always optimistic about my } \\
\quad \text { future (1) }\end{array}$ & -.271 & 6.696 & .010 & .763 & $.622-.936$ \\
\hline \multicolumn{6}{|l|}{ Decrease ( 9 items + Being a boy) } \\
\hline $\begin{array}{l}\text { Satisfaction with different life domains: Relations with other } \\
\text { people (1) }\end{array}$ & .224 & 4.655 & .031 & 1.251 & $1.021-1.534$ \\
\hline $\begin{array}{l}\text { Satisfaction with different life domains: Relations with } \\
\text { neighbours (2) }\end{array}$ & -.184 & 7.700 & .006 & .832 & $.730-.947$ \\
\hline BMLSS: Family (1) & .252 & 4.263 & .039 & 1.286 & $1.013-1.634$ \\
\hline BMLSS: Family (2) & -.235 & 4.483 & .034 & .791 & $.636-.983$ \\
\hline BMLSS: Myself (2) & -.498 & 20.014 & $<.001$ & .608 & $.489-.756$ \\
\hline $\begin{array}{l}\text { Self-concept: My family would help me with any } \\
\text { kind of problem (1) }\end{array}$ & .304 & 8.192 & .004 & 1.355 & $1.100-1.668$ \\
\hline $\begin{array}{l}\text { Self-concept: My family would help me with any } \\
\text { kind of problem (2) }\end{array}$ & -.219 & 4.680 & .031 & .803 & $.658-.980$ \\
\hline $\begin{array}{l}\text { Life optimism: If something can go wrong for me, } \\
\text { it will (1) }\end{array}$ & .153 & 5.064 & .024 & 1.166 & $1.020-1.333$ \\
\hline $\begin{array}{l}\text { Life optimism: I'm always optimistic about my } \\
\quad \text { future (1) }\end{array}$ & -.258 & 7.675 & .006 & .773 & $.644-.927$ \\
\hline Gender $=$ Being a boy & .633 & 6.159 & .013 & 1.883 & $1.142-3.105$ \\
\hline
\end{tabular}

(1) first year of data collection / (2) second year of data collection

The model fit was adequate for the final girls' model $\left(X_{88}^{2}=269.250, p<.001 ; \mathrm{R}^{2}\right.$ Nagelkerke $=.585$ ) . 
Table 6 Regression on OLS for satisfaction with different life domains, the satisfaction domains of the BMLSS, self-concept, core affects, social support and life optimism, boys only (category of reference: remaining the same)

\begin{tabular}{|c|c|c|c|c|c|}
\hline & Beta & $\mathrm{t}$ & $p$-value & O.R. & C.I. \\
\hline \multicolumn{6}{|l|}{ Increase ( 7 items) } \\
\hline Values aspired to: Money (2) & .292 & 10.309 & .001 & 1.339 & $1.121-1.601$ \\
\hline Self-concept: I feel happy at home (1) & -.896 & 9.414 & .002 & .408 & $.230-.724$ \\
\hline Self-concept: I am very criticized at home (2) & .159 & 3.922 & .048 & 1.173 & $1.002-1.373$ \\
\hline $\begin{array}{l}\text { Social support: My family holds a lot of esteem } \\
\text { for me ( } 2)\end{array}$ & -.398 & 4.310 & .038 & 672 & $.461-.978$ \\
\hline $\begin{array}{l}\text { Social support: My friends care about my } \\
\text { well-being ( } 2 \text { ) }\end{array}$ & -.337 & 6.057 & .014 & .714 & $.546-.934$ \\
\hline $\begin{array}{l}\text { Social support: My friends and I have done much } \\
\text { for each other (2) }\end{array}$ & .459 & 6.118 & .013 & 1.582 & $1.100-2.275$ \\
\hline $\begin{array}{l}\text { Life optimism: I'm always optimistic about my } \\
\text { future (1) }\end{array}$ & -.377 & 4.359 & .037 & .686 & $.481-.977$ \\
\hline \multicolumn{6}{|l|}{ Decrease (7 items) } \\
\hline BMLSS: Experience as a student (1) & -.418 & 5.556 & .018 & .658 & $.465-.932$ \\
\hline BMLSS: Myself (2) & -.868 & 15.139 & $<.001$ & .420 & $.271-.650$ \\
\hline $\begin{array}{l}\text { Self-concept: My family would help me with } \\
\text { any kind of problem (1) }\end{array}$ & .629 & 5.324 & .021 & 1.875 & $1.099-3.198$ \\
\hline $\begin{array}{l}\text { Social support: My friends care about my } \\
\text { well-being (1) }\end{array}$ & -.270 & 4.235 & .040 & .763 & $.590-.987$ \\
\hline $\begin{array}{l}\text { Social support: My friends and I have done much } \\
\text { for each other (2) }\end{array}$ & .334 & 5.547 & .019 & 1.396 & $1.058-1.844$ \\
\hline $\begin{array}{l}\text { Life optimism: If something can go wrong for me, } \\
\text { it will (1) }\end{array}$ & .245 & 4.435 & .035 & 1.277 & $1.017-1.604$ \\
\hline $\begin{array}{l}\text { Life optimism: I'm always optimistic about my } \\
\text { future (2) }\end{array}$ & -.450 & 6.054 & .014 & .638 & $.446-.913$ \\
\hline
\end{tabular}

(1) first year of data collection / (2) second year of data collection

Table 7 shows those items that are significant in the final model solely in the case of girls. Eleven items contribute to explaining the increase in OLS scores. They belong to the instrument measuring satisfaction with different life domains, the BMLSS, values aspired to, self-concept and core affects. Seven of the eleven items refer to responses given in the first year of data collection and four to responses given in the second year. Six items have a negative contribution, i.e., they help to reduce the likelihood of an increase in OLS. Three items contribute to explaining the decrease in OLS scores, plus the fact of belonging to the second cohort. They refer to the instrument measuring satisfaction with life domains and the BMLSS. One item refers to responses given in the first year of data collection and two to responses given in the second year. All of them excepting one have a negative contribution, i.e., they help to reduce the likelihood of a decrease in OLS. 
Table 7 Regression on OLS for satisfaction with different life domains, the satisfaction domains of the BMLSS, self-concept, core affects, social support and life optimism, girls only (category of reference: remaining the same)

\begin{tabular}{|c|c|c|c|c|c|}
\hline & Beta & $\mathrm{t}$ & $p$-value & O.R. & C.I. \\
\hline \multicolumn{6}{|l|}{ Increase (11 items) } \\
\hline $\begin{array}{l}\text { Satisfaction with different life domains: Relations } \\
\text { with other people (1) }\end{array}$ & -.377 & 4.586 & .032 & .686 & $.485-.969$ \\
\hline $\begin{array}{l}\text { Satisfaction with different life domains: Security } \\
\text { for the future (1) }\end{array}$ & -.268 & 4.725 & .030 & .765 & $.600-.974$ \\
\hline Satisfaction with different life domains: Sports (1) & -.185 & 4.173 & .041 & .832 & $.697-.993$ \\
\hline BMLSS: The place I live (1) & .340 & 4.429 & .035 & 1.405 & $1.024-1.928$ \\
\hline Values aspired to: Money (2) & .178 & 6.980 & .008 & 1.195 & $1.047-1.364$ \\
\hline Self-concept: I feel happy at home (1) & -.326 & 4.104 & .043 & .722 & $.527-.989$ \\
\hline $\begin{array}{l}\text { Self-concept: My family would help me with any } \\
\text { kind of problem (1) }\end{array}$ & .475 & 7.101 & .008 & 1.608 & $1.134-2.281$ \\
\hline $\begin{array}{l}\text { Self-concept: My family would help me with any } \\
\text { kind of problem (2) }\end{array}$ & -.419 & 4.057 & .044 & .658 & $.437-.989$ \\
\hline Self-concept: I am afraid of some things (2) & -.165 & 4.033 & .045 & .848 & $.722-.996$ \\
\hline Core affects: Satisfied (1) & -.361 & 7.948 & .005 & .697 & $.542-.896$ \\
\hline Core affects: Happy (2) & .686 & 6.717 & .010 & 1.985 & $1.182-3.333$ \\
\hline \multicolumn{6}{|l|}{ Decrease ( 3 items $+2^{\text {nd }}$ cohort $)$} \\
\hline $\begin{array}{l}\text { Satisfaction with different life domains: Relations } \\
\text { with other people (1) }\end{array}$ & .457 & 7.299 & .007 & 1.580 & $1.134-2.201$ \\
\hline $\begin{array}{l}\text { Satisfaction with different life domains: Relations } \\
\text { with neighbours (2) }\end{array}$ & -.243 & 5.925 & .015 & .784 & $.645-.954$ \\
\hline BMLSS: Myself (2) & -.375 & 6.163 & .013 & .688 & $.512-.924$ \\
\hline Cohort $=2$ & -1.336 & 4.054 & .044 & .263 & $.072-.965$ \\
\hline
\end{tabular}

(1) first year of data collection / (2) second year of data collection

\subsection{Happiness with Overall Life (HOL)}

The highest percentage corresponds to those participants stating that their HOL has remained the same over a one-year period, followed by those who experienced a decrease (Table 8).

A logistic regression was performed, taking HOL as the dependent variable for each instrument, considering the 2 years of data collection separately; gender and cohort were also included. The following items and constructs were included: (a) satisfaction with different life domains, (b) the satisfaction domains included in the BMLSS, (c) values aspired to, (d) self-concept, (e) core affects, (f) social support and (g) life optimism. Those items which are significant for each partial model are shown in Table 9.

A final HOL model was performed taking into account only those indicators included in Table 9. Gender and cohort were also included in the analysis, since they were significant in some of the partial models. The model fit was adequate for the final model $\left(X_{98}^{2}=294.492, p<.001 ; \mathrm{R}^{2}\right.$ Nagelkerke $\left.=.464\right)$. 
Table 8 Percentage of cases in which the HOL has increased, remained the same or decreased from the first to the second year of data collection

\begin{tabular}{llll}
\hline & \multicolumn{2}{l}{$\%$ of cases } & \\
\cline { 2 - 4 } & Boys & Girls & Total \\
\hline Increase & 21.1 & 16.5 & 18.4 \\
Remaining the same & 42.1 & 41.6 & 41.8 \\
Decrease & 36.8 & 41.9 & 39.7 \\
\hline
\end{tabular}

Globally, the final model correctly classifies a $64.2 \%$ of the cases $(33.7 \%$ for the increasing group, $72.9 \%$ for the no difference group and $69.2 \%$ for the decreasing

Table 9 Regression on HOL of satisfaction with different life domains, the satisfaction domains of the BMLSS, self-concept, core affects, social support and life optimism, whole sample (category of reference: remaining the same)

\begin{tabular}{|c|c|c|}
\hline & Increase & Decrease \\
\hline $\begin{array}{l}\text { Satisfaction with different } \\
\text { life domains }\end{array}$ & $\begin{array}{l}\text { Standard of living (-) (1) } \\
\text { Yourself }(-)(1) \\
\text { Sports (-) (2) }\end{array}$ & $\begin{array}{l}\text { Present security (+) (1) } \\
\text { Father }(+)(1) \\
\text { Relations with neighbours (-) (1) } \\
\text { Standard of living (-) (2) } \\
\text { All the people living with you (-) (2) } \\
\text { Own body (-) (2) }\end{array}$ \\
\hline BMLSS & $\begin{array}{l}\text { Friends (-) (1) } \\
\text { Experience as a student (-) (1) } \\
\text { Experience as a student }(+)(2)\end{array}$ & $\begin{array}{l}\text { Family (+) (1) } \\
\text { Myself (+) (1) } \\
\text { Family (-) (2) } \\
\text { Friends (-) (2) } \\
\text { Myself (-) (2) }\end{array}$ \\
\hline Values aspired to & Family (-) (1) & $\begin{array}{l}\text { Relations with other people (+) (1) } \\
\text { Sympathy (-) (2) }\end{array}$ \\
\hline Self-concept & $\begin{array}{l}\text { My teachers consider me a good } \\
\text { worker }(-)(1) \\
\text { I feel happy at home }(-)(1) \\
\text { I work a lot in class }(+)(1) \\
\text { My parents give me confidence }(+)(1) \\
\text { I am afraid of some things }(+)(1) \\
\text { I feel loved by my parents }(+)(2)\end{array}$ & $\begin{array}{l}\text { I am very criticized at home (-) (1) } \\
\text { I feel happy at home }(+)(1) \\
\text { My parents give me confidence (+) (1) } \\
\text { I am very criticized at home (+) (2) } \\
\text { I get friends easily }(-)(2) \\
\text { I feel happy at home }(-)(2) \\
\text { My parents give me confidence (-) (2) } \\
\text { I like how I am physically (-) (2) } \\
\text { I feel loved by my parents (+) (2) } \\
\text { Many things make me nervous (+) (2) }\end{array}$ \\
\hline Core affects & $\begin{array}{l}\text { Active, with energy (-) (1) } \\
\text { Bored (-) (2) }\end{array}$ & $\begin{array}{l}\text { Fortunate (+) (1) } \\
\text { Active, with energy (-) (2) } \\
\text { Fortunate (-) (2) } \\
\text { Worried (+) (2) }\end{array}$ \\
\hline Social support & $\begin{array}{l}\text { My family holds a lot of affection } \\
\text { (love) for me (+) (2) }\end{array}$ & $\begin{array}{l}\text { I'm really admired by my family (-) (2) } \\
\text { I feel attached to the members of } \\
\text { my family (-) (2) }\end{array}$ \\
\hline Life optimism & & $\begin{array}{l}\text { I'm always optimistic about my } \\
\text { future }(+)(1) \\
\text { I rarely count on good things } \\
\text { happening to me }(+)(2)\end{array}$ \\
\hline
\end{tabular}

(-) negative contribution / (+) positive contribution

(1) first year of data collection / (2) second year of data collection 
group). Table 10 shows those items that are significant in the final model. Five items contribute to explaining the increase in HOL scores. They belong to the instrument measuring satisfaction with different life domains, the BMLSS, core affects and social support. Three of the five items refer to responses given in the first year of data collection and two to responses given in the second year. Three have a negative contribution, i.e., they help to reduce the likelihood of an increase in HOL. Ten items contribute to explaining the decrease in HOL score. They belong to the instrument measuring satisfaction with different life domains, to the BMLSS, to values aspired to, self-concept and life optimism. Six of the ten items refer to responses given in the first year of data collection and four to responses given in the second year. Six have a negative contribution, i.e., they help to reduce the likelihood of a decrease in HOL.

\subsection{Happiness With Overall Life (HOL) and Gender}

The next stage was to calculate the final HOL model while considering boys and girls separately.

Table 10 Regression on HOL of satisfaction with different life domains, the satisfaction domains of the BMLSS, self-concept, core affects, social support and life optimism, whole sample (category of reference: remaining the same)

\begin{tabular}{|c|c|c|c|c|c|}
\hline & Beta & $\mathrm{t}$ & $p$-value & O.R. & C.I. \\
\hline \multicolumn{6}{|l|}{ Increase ( 5 items) } \\
\hline $\begin{array}{l}\text { Satisfaction with different life domains: Standard } \\
\text { of living (1) }\end{array}$ & -.471 & 11.340 & .001 & .624 & $.474-.821$ \\
\hline BMLSS: Friends (1) & -.316 & 6.189 & .013 & .729 & $.569-.935$ \\
\hline BMLSS: Experience as a student (2) & .254 & 3.961 & .047 & 1.289 & $1.004-1.656$ \\
\hline Core affects: Fortunate (1) & -.217 & 4.526 & .033 & .805 & $.659-.983$ \\
\hline $\begin{array}{l}\text { Social support: My family holds a lot of affection } \\
\text { (love) for me (2) }\end{array}$ & .322 & 4.609 & .032 & 1.380 & $1.028-1.851$ \\
\hline \multicolumn{6}{|l|}{ Decrease (10 items) } \\
\hline $\begin{array}{l}\text { Satisfaction with different life domains: Present } \\
\text { security (1) }\end{array}$ & .248 & 7.491 & .006 & 1.281 & $1.073-1.530$ \\
\hline $\begin{array}{l}\text { Satisfaction with different life domains: Relations } \\
\text { with neighbours (1) }\end{array}$ & -.125 & 3.898 & .048 & .883 & $.780-.999$ \\
\hline $\begin{array}{l}\text { Satisfaction with different life domains: Standard } \\
\text { of living (2) }\end{array}$ & -.249 & 4.069 & .044 & .780 & $.613-.993$ \\
\hline $\begin{array}{l}\text { Satisfaction with different life domains: All people } \\
\text { living with you (2) }\end{array}$ & -.398 & 10.301 & .001 & .672 & $.527-.857$ \\
\hline BMLSS: Myself (1) & .252 & 4.898 & .027 & 1.287 & $1.029-1.610$ \\
\hline BMLSS: Friends (2) & -.251 & 4.932 & .026 & .778 & $.623-.971$ \\
\hline BMLSS: Myself (2) & -.256 & 5.486 & .019 & .774 & $.624-.959$ \\
\hline Values aspired to: Relations with other people (1) & .217 & 5.138 & .023 & 1.243 & $1.030-1.500$ \\
\hline Self-concept: I am afraid of some things (1) & -.103 & 5.262 & .022 & .902 & $.826-.985$ \\
\hline $\begin{array}{l}\text { Life optimism: I'm always optimistic about my } \\
\text { future (1) }\end{array}$ & .229 & 5.239 & .022 & 1.257 & $1.033-1.528$ \\
\hline
\end{tabular}

(1) first year of data collection / (2) second year of data collection 


\subsubsection{Boys}

The highest percentage corresponds to those boys stating that their HOL has remained the same over a one-year period, followed by those who experienced a decrease (Table 8). The model fit was adequate for the final boys' model $\left(X^{2}{ }_{96}=180.253\right.$, $p<.001 ; \mathrm{R}^{2}$ Nagelkerke $\left.=.597\right)$.

Table 11 shows those items that are significant in the final model solely in the case of boys. Six items contribute to explaining the increase in HOL scores. They belong to the instrument measuring satisfaction with different life domains, the BMLSS, values aspired to and self-concept. Three of the six items refer to responses given in the first year of data collection and three to responses given in the second year. Three items have a negative contribution, i.e., they help to reduce the likelihood of an increase in HOL. Four items contribute to explaining the decrease in HOL. They belong to the different life satisfaction domains, the BMLSS and the instrument measuring selfconcept. Two of the four items refer to responses given in the first year of data collection and two to responses given in the second year. Two of them have a negative contribution, i.e., they help to reduce the likelihood of a decrease in HOL.

\subsubsection{Girls}

The percentage of girls stating that their HOL has remained the same over a one-year period is almost the same as those who experienced a decrease (Table 8). The model fit was adequate for the final girls' model $\left(X_{96}^{2}=232.296, p<.001 ; \mathrm{R}^{2}\right.$ Nagelkerke $\left.=.590\right)$.

Table 12 shows those items that are significant in the final model solely in the case of girls. Eleven items contribute to explaining the increase in HOL scores, plus the fact

Table 11 Regression on HOL of satisfaction with different life domains, the satisfaction domains of the BMLSS, self-concept, core affects, social support and life optimism, boys only (category of reference: remaining the same)

\begin{tabular}{|c|c|c|c|c|c|}
\hline & Beta & $\mathrm{t}$ & $p$-value & O.R. & C.I. \\
\hline \multicolumn{6}{|l|}{ Increase (6 items) } \\
\hline $\begin{array}{l}\text { Satisfaction with different life domains: Standard } \\
\text { of living (1) }\end{array}$ & -.767 & 6.898 & .009 & .465 & $.262-.823$ \\
\hline Satisfaction with different life domains: Father (1) & .431 & 7.485 & .006 & 1.539 & $1.130-2.095$ \\
\hline BMLSS: Experience as a student (2) & .729 & 6.910 & .009 & 2.073 & $1.204-3.569$ \\
\hline Values aspired to: Family (1) & -.666 & 6.737 & .009 & .514 & $.311-.849$ \\
\hline Self-concept: I feel loved by my parents (2) & .664 & 4.423 & .035 & 1.942 & $1.046-3.606$ \\
\hline Self-concept: I like how I am physically (2) & -.576 & 6.369 & .012 & .562 & $.359-.879$ \\
\hline \multicolumn{6}{|l|}{ Decrease (4 items) } \\
\hline $\begin{array}{l}\text { Satisfaction with different life domains: Present } \\
\text { security (1) }\end{array}$ & .457 & 6.584 & .010 & 1.579 & $1.114-2.238$ \\
\hline $\begin{array}{l}\text { Satisfaction with different life domains: All people } \\
\text { living with you (2) }\end{array}$ & -.848 & 11.426 & .001 & .428 & $.262-.700$ \\
\hline$B M L S S:$ Experience as a Student (2) & .357 & 4.687 & .030 & 1.429 & $1.034-1.974$ \\
\hline Self-concept: I am afraid of some things (1) & -.209 & 6.366 & .012 & .811 & $.689-.954$ \\
\hline
\end{tabular}

(1) first year of data collection / (2) second year of data collection 
Table 12 Regression on HOL of satisfaction with different life domains, the satisfaction domains of the BMLSS, self-concept, core affects, social support and life optimism, girls only (category of reference: remaining the same)

\begin{tabular}{|c|c|c|c|c|c|}
\hline & Beta & $\mathrm{t}$ & $p$-value & O.R. & C.I. \\
\hline \multicolumn{6}{|l|}{ Increase (11 items $+2^{\text {nd }}$ cohort $)$} \\
\hline $\begin{array}{l}\text { Satisfaction with different life domains: Standard } \\
\text { of living (1) }\end{array}$ & -.490 & 4.267 & .039 & .613 & $.385-.975$ \\
\hline BMLSS: Friends (1) & -.470 & 5.415 & .020 & .625 & $.421-.929$ \\
\hline BMLSS: Family (2) & .598 & 4.578 & .032 & 1.819 & $1.052-3.148$ \\
\hline Values aspired to: Relations with people (1) & .608 & 7.456 & .006 & 1.837 & $1.187-2.843$ \\
\hline Self-concept: I get friends easily (2) & .338 & 4.720 & .030 & 1.403 & $1.034-1.903$ \\
\hline Self-concept: I feel happy at home (2) & -.545 & 4.504 & .034 & .580 & $.351-.959$ \\
\hline Self-concept: My parents give me confidence (2) & .441 & 4.665 & .031 & 1.555 & $1.042-2.320$ \\
\hline Self-concept: Many things make me nervous (2) & .221 & 5.720 & .017 & 1.247 & $1.041-1.494$ \\
\hline Core affects: Fortunate (1) & -.349 & 4.426 & .035 & .706 & $.510-.976$ \\
\hline Social support: I'm really admired by my family (2) & -.449 & 6.127 & .013 & .638 & $.447-.911$ \\
\hline $\begin{array}{l}\text { Life optimism: I rarely count on good things happening } \\
\text { to me (2) }\end{array}$ & -.377 & 4.461 & .035 & .686 & $.484-.973$ \\
\hline Cohort $=2$ & -2.564 & 6.042 & .014 & .077 & $.010-.595$ \\
\hline \multicolumn{6}{|l|}{ Decrease (6 items) } \\
\hline BMLSS: Friends (2) & -.353 & 4.236 & .040 & .702 & $.502-.983$ \\
\hline$B M L S S:$ Myself (2) & -.496 & 9.263 & .002 & .609 & $.443-.838$ \\
\hline Self-concept: I feel happy at home (2) & -.402 & 3.906 & .048 & .669 & $.449-.997$ \\
\hline Core affects: Fortunate (2) & -.261 & 3.909 & .048 & .770 & $.595-.998$ \\
\hline Social support: I'm really admired by my family (2) & -.323 & 5.408 & .020 & .724 & $.551-.950$ \\
\hline Life optimism: I'm always optimistic about my future (1) & .443 & 8.387 & .004 & 1.558 & $1.154-2.103$ \\
\hline
\end{tabular}

(1) first year of data collection / (2) second year of data collection

of belonging to the $2^{\text {nd }}$ cohort. They refer to the instrument measuring satisfaction with different life domains, the BMLSS, values aspired to, self-concept, core affects, social support and life optimism. Four of the eleven items refer to responses given in the first year of data collection and seven to responses given in the second year. Seven items have a negative contribution, i.e., they help to reduce the likelihood of an increase in HOL. Six items contribute to explaining the decrease in HOL scores. They belong to the BMLSS, self-concept, core affects, social support and life optimism. One of the six items refers to responses given in the first year of data collection and five to responses given in the second year. Five of them have a negative contribution, i.e., they help to reduce the likelihood of a decrease in HOL.

\section{Discussion}

\subsection{Age and Subjective Well-Being}

Age was explored in this study through the cohort participants belonged to. This variable was included in all partial models as well as in the final models. 
Unexpectedly, it has only limited explanatory power since it only appeared as significant in girls' models, both for OLS and HOL. Belonging to the $2^{\text {nd }}$ cohort contributed negatively to a decrease in OLS and positively to an increase in HOL levels. The $2^{\text {nd }}$ cohort corresponds to the transition from primary to secondary school in the Spanish education system. Many studies consider this period as highly important for future school achievement and integration (Reschly and Christenson 2006; Anderson and Havsy 2001). The results obtained seem to suggest that this transition may affect girls' SWB more than that of boys. This observation, when taken together with that made by other authors according to which girls' levels of SWB are lower than boys in at-risk samples of adolescents (Tomyn et al. 2015; Llosada-Gistau et al. 2015), reinforces the idea that girls' homeostatic mechanism might be more sensitive to external circumstances. Without further research, such a statement may be premature, however.

\subsection{Gender and Subjective Well-Being}

The highest percentages for boys and girls correspond to those stating that their OLS has decreased over a one-year period. Regarding HOL, the highest percentage for boys corresponds to the "remaining the same" group while for girls almost the same percentage is obtained by the "decrease" and "remaining the same" groups. When the sample as a whole is considered, being a boy contributes negatively to predicting the decrease in OLS levels.

As expected, important gender differences also emerge when their respective multinomial logistic regression models are compared. Only three indicators contribute to explaining both boys' and girls' models when OLS is taken as the dependent variable. They are the following: (1) Values: Money, (2) Self-concept: I feel happy at home, and (3) BMLSS: Myself. All of these correspond to the same year of data collection and have the same sign. Only one indicator is shared in both boys' and girls' models when HOL is the dependent variable: Satisfaction with different life domains: Standard of living (both sign and year of data collection coincide). This result is in line with previous findings showing that boys and girls differ in the life domains most contributing to their SWB (Casas et al. 2007b; Chui and Wong 2015) and suggests that practitioners should consider gender differences when designing actions aimed at increasing adolescents' SWB.

\subsection{Measuring instruments and Subjective Well-Being}

When changes between the first and second years of data collection are analysed, and taking into account the SWB assessment instrument considered, we see that the highest percentage of responses for OLS corresponds to those participants who state that their levels have decreased. In contrast, the highest percentage for HOL corresponds to those participants who state that their levels have remained the same. The comparison between the multinomial logistic regression on OLS and that on HOL shows that just four indicators contribute to explaining changes in both OLS and HOL, considering the "increase" and "decrease" groups separately (Social support: My family holds a lot of affection (love) for me/Satisfaction with life domains: Relations with neighbours/ BMLSS: Myself/Life optimism: I'm always optimistic about my future). One of these four indicators does not belong to the same year of data collection (Satisfaction with life 
domains: Relations with neighbours) and another does not coincide in sign (Life optimism: I'm always optimistic about my future). As expected, the above results show that OLS and HOL do not measure the same thing, a result in line with other studies (Casas et al. 2012) and meaning that their indistinct use is incoherent. They also show that predictors of change for OLS and HOL are essentially different, this finding being an innovative contribution made by the present article.

\subsection{Factors Related to Subjective Well-Being}

Twenty-three indicators of the ninety-four included in the questionnaire are predictive of changes in OLS and fifteen are predictive of changes in HOL. Core affects (Feeling happy) and social support (My family holds a lot of affection -love-for me) are the indicators that contribute most to explaining increases in OLS and HOL, respectively. Social support has been highlighted on numerous occasions as being strongly connected to SWB (see, for instance, the work by Ronen et al. 2014), while core affects have only been considered more recently (Davern et al. 2007; Blore et al. 2011; Tomyn and Cummins 2011a). The importance of family support is also observed when we focus on the indicators that contribute most to a decrease in OLS, because top of the list is My family would help me with any kind of problem, which belongs to the self-concept instrument, and concretely to the family self-concept factor. With regard to decreased HOL values, the indicator that contributes most is Satisfaction with myself, which belongs to the BMLSS.

The results obtained suggest that actions to increase SWB in adolescence should be specific and based on those factors with a greater impact on SWB in a specific group. From an academic point of view, the results suggest that researchers should expand their SWB models by including factors which have traditionally not been considered simultaneously. To cite just one example, Cummins' homeostatic model includes personality, perception of control, self-esteem and optimism, but does not include values aspired to or social support.

There is no instrument with fewer than two indicators predictive of OLS or HOL, thus confirming, on the one hand, the strong relation that exists between specific and global evaluations of SWB (Casas et al. 2007b) and, on the other, that the five instruments included here are closely related to global evaluations of SWB (Casas et al. 2007b). These observations reinforce Campbell et al. (1976) conviction that both OLS and HOL are necessary in understanding SWB, and also our initial assumption that SWB is composed of both hedonic and eudaimonic components.

Those indicators that contribute to an increase in OLS or HOL are not necessarily the same as those contributing to their decrease, although some exceptions do exist: 1) For the final OLS model: My family would help me with any kind of problem (selfconcept scale) and I'm always optimistic about my future (life optimism scale), and 2) For the final HOL model: Standard of living (Satisfaction with different life domains) and Friends (BMLSS). Theoretical models explaining SWB should take into account factors contributing to both an increase and decrease in SWB. This statement could also be extended to social policy aimed at improving children's and adolescents' lives, which should ideally take into account their perceptions of their own SWB (see, for instance, the work by Fattore et al. 2009). 
The indicators that appear as significant in the OLS and HOL models belong to the first and second years of data collection. This, too is an innovative finding of this article. On only two occasions do the final models include the same indicator measurement over the 2 years; these help to explain both the increase and decrease in SWB. This is the case of My family would help me with any kind of problem (OLS model) and Standard of living (HOL model).

Some combinations between indicators with a positive and others with a negative sign, which are apparently counter-intuitive, would suggest that the use of non-linear techniques of analysis is recommendable in the future (see, for instance, González et al. 2006; González et al. 2010). This is the case, for example, with the indicator I feel happy at home (self-concept scale), which has a negative sign in the first year of data collection and a positive sign in the second; both contribute to explaining the increase in OLS levels.

The limited number of participants in each cohort meant that differences found between the cohorts in the three groups considered ("increase", "remaining the same" and "decrease" of OLS and HOL) were not explored. Had it been possible, it would have been helpful to determine whether the impact of different factors on SWB changes throughout adolescence. In order to simplify the interpretation of findings from multinomial logistic regression models, the degree of change in OLS and HOL levels was not considered in the forming of the three above-mentioned groups, although important differences may exist between those participants whose scores have changed the most and those that have changed the least.

Although a wide range of instruments has been used, others not considered here, such as perception of control, should also be included in future studies. Future studies could also include a measurement of turbulence, understood as the experiencing of multiple changes in life circumstances that greatly disrupt children's and adolescents' lives (see, for instance, the work by Moore et al. 2009, and the results obtained in Dinisman et al. 2012). As the sample used here is not representative of the overall Catalan population, the results cannot be generalized to other adolescents of the same age range. A larger number of data collections would also be necessary to explore whether the changes detected remain stable or not and which factors help explain different possible patterns in such change. Knowing whether the "remaining the same" group maintains its higher scores for the different factors evaluated here in comparison with the other two groups over time would also be useful when designing actions to improve SWB in adolescence.

Acknowledgments This article is based on data collected in the research project with reference number PSI2010-19404 and PSI2013-41512-P, founded by the Spanish Ministry of Economy and Competitiveness (MINECO). Particular thanks are due to Barney Griffiths for editing English.

\section{References}

Abdel-Khalek, A. M. (2006). Measuring happiness with a single item scale. Social Behavior and Personality: An International Journal, 34(2), 139-150. doi:10.2224/sbp.2006.34.2.139.

Anderson, A. R., \& Havsy, L. (2001). Check \& connect: an examination of the middle school transition. Washington, DC: Paper presented at the annual meeting of the National Association of School Psychologists. 
Antaramian, S. P., Huebner, E. S., \& Valois, R. F. (2008). Adolescent life satisfaction. Applied Psychology: An International Review, 57, 112-126. doi:10.1111/j.1464-0597.2008.00357.x.

Argyle, M. (1993). Psicología y calidad de vida. [Psychology and quality of life]. Intervención Psicosocial, 2(6), 5-15.

Baltatescu, S. (2006). Comparative results and psychometric properties of the Personal Well-Being IndexRomania (old and new versions) with an adolescent sample- a preliminary analysis. Retrieved from http: www.sergiubaltatescu.info/content/comparativePWI website.

Ben-Arieh, A., Casas, F., Frones, I., \& Korbin, J. E. (2014). Multifaceted concept of child well-being. Handbook of child well-being, vol. 1 (pp. 1-27). Dordrecht: Springer.

Blore, J. D., Stokes, M. A., Mellor, D., Firth, L., \& Cummins, R. A. (2011). Comparing multiple discrepancies theory to affective models of subjective well-being. Social Indicators Research, 100, 1-16. doi:10.1007/ s11205-010-9599-2.

Bradburn, N. M. (1969). The structure of psychological well-being. Chicago: Aldine.

Bradford, R., Rutheford, D. L., \& John, A. (2002). Quality of life in young people: ratings and factor structure of the quality of life profile-adolescent version. Journal of Adolescence, 25, 261-274. doi:10.1006/jado. 2002.0469.

Campbell, A., Converse, P. E., \& Rogers, W. L. (1976). The quality of American life: perceptions, evaluations, and satisfactions. New York: Russell Sage.

Cantril, H. (1965). The pattern of human concerns. New Brunswick: Rutgers Univ. Press.

Casas, F., Coenders, G., Cummins, R. A., González, M., Figuer, C., \& Malo, S. (2008). Does subjective wellbeing show a relationship between parents and their children? Journal of Happiness Studies, 9(2), 197-205. doi:10.1007/s10902-007-9044-7.

Casas, F., Figuer, C., González, M., \& Malo, S. (2007a). The values adolescents aspire to, their well-being and the values parents aspire to for their children. Social Indicators Research, 84, 271-290. doi:10.1007/ s11205-007-9141-3.

Casas, F., Figuer, C., González, M., Malo, S., Alsinet, C., \& Subarroca, S. (2007b). The well-being of 12- to 16-year-old adolescents and their parents: results from 1999 to 2003 Spanish samples. Social Indicators Research, 83, 87-115. doi:10.1007/s11205-006-9059-1.

Casas, F., Sarriera, J. C., Abs, D., Coenders, G., Alfaro, J., Saforcada, E., \& Tonon, G. (2012). Subjective indicators of personal well-being among adolescents. Performance and results for different scales in Latinlanguage speaking countries: A contribution to the international debate. Child Indicators Research, 5(1), 1-28. doi:10.1007/s12187-011-9119-1.

Chui, W. H., \& Wong, M. Y. H. (2015). Gender differences in happiness and life satisfaction among adolescents in Hong Kong: relationships and self-concept. Social Indicators Research. doi:10.1007/ s11205-015-0867-z.

Cummins, R. A. (2010). Subjective wellbeing, homeostatically protected mood and depression: a synthesis. Journal of Happiness Studies, 11, 1-17. doi:10.1007/s10902-009-9167-0.

Cummins, R. A. (2013). Understanding the well-being of children and adolescents through homeostastic theory. Handbook of child well-being, vol. 2 (pp. 635-662). Dordrecht: Springer.

Cummins, R. A., \& Cahill, J. (2000). Avances en la comprensión de la calidad de vida subjetiva. [Advances in the comprehension of subjective quality of life]. Intervención Psicosocial, 9(2), 185-198.

Cummins, R. A., \& Gullone, E. (2000). Why we should not use 5-point Likert scales: The case for subjective quality of life measurement. Proceedings Second International Conference on Quality of Life in Cities (pp. 74-93). Singapore: National University of Singapore.

Cummins, R. A., Eckersley, R., van Pallant, J., Vugt, J., \& Misajon, R. (2003). Developing a national index of subjective well-being: the Australian unity well-being index. Social Indicators Research, 64, 159-190.

Currie, C., Zanotti, C., Morgan, A., Currie, D., de Looze, M., Roberts, C., \& Rasmussen, V. B. (2012). Social determinants of health and well-being among young people. Health Behaviour in School-aged Children (HBSC) study: international report from the 2009/2010 survey. In W.R.O.f. Europe (Ed.), Health policy for children and adolescents (vol. 6). Copenhagen: Who Regional Office for Europe.

Davern, M. T., Cummins, R. A., \& Stokes, M. (2007). Subjective wellbeing as an affective-cognitive construct. Journal of Happiness Studies, 8(4), 429-449. doi:10.1007/s10902-007-9066-1.

Diener, E. (1994). El bienestar subjetivo. [Subjective well-being]. Intervención Psicosocial, 3(8), 67-113.

Dinisman, T., Montserrat, C., \& Casas, F. (2012). The subjective well-being of Spanish adolescents: variations according to different living arrangements. Children and Youth Services Review, 34, 2374-2380. doi:10. 1016/j.childyouth.2012.09.005.

Fattore, T., Mason, J., \& Watson, E. (2009). When children are asked about their well-being: towards a framework for guiding policy. Child Indicators Research, 2, 57-77. doi:10.1007/s12187-008-9025-3. 
Garcia, D. (2011). Two models of personality and well-being among adolescents. Personality and Individual Differences, 50, 1208-1212. doi:10.1016/j.paid.2011.02.009.

García, F., \& Musitu, G. (1999). AF5: Autoconcepto forma 5. [Self-concept A Form]. Madrid: TEA Ediciones.

Gilman, R., \& Huebner, E. S. (2006). Characteristics of adolescents who report very high life satisfaction. Journal of Youth and Adolescence, 35(3), 311-319. doi:10.1007/s10964-006-9036-7.

Goldbeck, L., Schmitz, T. G., Nesier, T., Herschbach, P., \& Henrich, G. (2007). Life satisfaction decreases during adolescence. Quality of Life Research, 16, 969-979. doi:10.1007/s11136-007-9205-5.

González, M., Casas, F., \& Coenders, G. (2006). A complexity approach to psychological well-being in adolescence: major strengths and methodological issues. Social Indicators Research, 80, 267-295. doi:10. 1007/s11205-005-5073-y.

González-Carrasco, M., Casas, F., Malo, S., Viñas, F. \& Dinisman, T. (2016). Changes in subjective wellbeing through the adolescent years: differences by gender. Journal of Happiness Studies. doi:10.1007/ s10902-016-9717-1.

González, M., Coenders, G., Saez, M., \& Casas, F. (2010). Non-linearity, complexity and limited measurement in the relationship between satisfaction with specific life domains and satisfaction with life as a whole. Journal of Happiness Studies, 11, 335-352. doi:10.1007/s10902-009-9143-8.

Holder, M. K., \& Klassen, A. (2010). Temperament and happiness in children. Journal of Happiness Studies, 11, 419-439. doi:10.1007/s10902-009-9149-2.

Holte, A. et al. (2014). Psychology of child well-being. Handbook of child well-being, vol. 1 (pp. 555-631). Dordrecht: Springer.

Huebner, E. S., Seligson, J. L., Valois, R. F., \& Suldo, S. M. (2006). A review of the brief multidimensional students' life satisfaction scale. Social Indicators Research, 79, 477-484. doi:10.1007/s11205-005-5395-9.

Lee, B. J., \& Yoo, M. S. (2015). Family, school, and community correlates of children's subjective well-being: an international comparative study. Child Indicators Research, 8, 151-175. doi:10.1007/s12187-0149285-Z.

Leung, C. Y., McBride-Chang, C., \& Lai, B. P. (2004). Relations among maternal parenting style, academic competence, and life satisfaction in Chinese early adolescents. Journal of Early Adolescence, 24, 113143.

Lippman, L. H., Moore, K. A., \& McIntosh, H. (2011). Positive indicators of child well-being: a conceptual framework, measures, and methodological issues. Applied Research in Quality of Life, 6, 425-449. doi: 10.1007/s11482-011-9138.6.

Liu, W., Mei, J., Tian, L.,\& Huebner, E. S. (2015). Age and gender differences in the relation between schoolrelated social support and subjective well-being in school among students. Social Indicators Research. doi:10.007/s11205-015-0873-1.

Llosada-Gistau, J., Montserrat, C., \& Casas, F. (2015). The subjective well-being of adolescents in residential care compared to that of the general population. Children and Youth Services Review, 52, 150-157. doi: 10.1016/j.childyouth.2014.11.007.

Malo, S., Bataller, S., Casas, F., Gras, M. E., \& González, M. (2011). Análisis psicométrico de la escala multidimensional de autoconcepto AF5 en una muestra de adolescentes y adultos de Cataluña. [Psychometric analysis of the multidimensional self-concept AF5 scale in a sample of adolescents and adults in Catalonia]. Psicothema, 23(4), 871-878.

Moore, K. A., Vandivere, S., Kinukawa, A., \& Ling, T. (2009). Creating a longitudinal indicator: an exploratory analysis if turbulence. Child Indicators Research, 2, 5-32. doi:10.1007/s12187-008-9023-5.

Olsson, C. A., McGee, R., Nada-Raja, S., \& Williams, S. (2013). A 32-year longitudinal study of child and adolescent pathways to well-being in adulthood. Journal of Happiness Studies, 14(3), 1069-1083. doi:10. 1007/s10902-012-9369-8.

Orejudo, S., Puyuelo, M., Fernández-Turrado, T., \& Ramos, T. (2012). Optimism in adolescence: a crosssectional study of the influence of family and peer group variables on junior high school students. Personality and Individual Differences, 52, 812-817. doi:10.1016/j.paid.2012.01.012.

Park, N. (2005). Life satisfaction among Korean children and youth: A developmental perspective. School Psychology International, 26, 209-223. doi:10.1177/0143034305052914.

Petito, F., \& Cummins, R. A. (2000). Quality of life in adolescence: the role of perceived control, parenting style, and social support. Behaviour Change, 17(3), 193-207. doi:10.1375/bech.17.3.196.

Raboteg-Saric, Z., \& Sakic, M. (2014). Relations of pareting styles and friendship quality to self-esteem, life satisfaction and happiness in adolescents. Applied Research in Quality of Life, 9, 749-765. doi:10.1007/ s11482-013-9268-0.

Reschly, A., \& Christenson, S. L. (2006). Promoting school completion. In G. Bear \& K. Minke (Eds.), Children's needs III: Understanding and addressing the developmental needs of children (pp. 102-113). Bethesda: National Association of School Psychologists. 
Ronen, T., Hamama, L., Rosenbaum, M., \& Mishely-Yarlap, A. (2014). Subjective well-being in adolescence: the role of self-control, social support, age, gender, and familiar crisis. Journal of Happiness Studies. doi: 10.1007/s10902-014-9585-5.

Russell, J. A. (2003). Core affect and the psychological construction of emotion. Psychological Review, 110, 145-172. doi:10.1037/0033-295X.110.1.145.

Ryan, R. M., \& Deci, E. L. (2001). On Happiness and human potentials: a review of research on hedonic and eudaimonic well-being. Annual Review of Psychology, 52, 141-166. doi:10.1146/annurev.psych.52.1. 141.

Saha, R., Huebner, E. S., Suldo, S., \& Valois, R. F. (2010). A longitudinal study of adolescent life satisfaction and parenting. Child Indicators Research, 3, 149-165. doi:10.1007/s12187-009-9050-x.

Scheier, M. F., Carver, C. S., \& Bridges, M. W. (1994). Distinguishing optimism from neuroticism (and trait anxiety, self-mastery, and self-esteem): a re-evaluation of the life orientation test. Journal of Personality and Social Psychology, 67, 1063-1078. doi:10.1037/0022-3514.67.6.1063.

Seligson, J. L., Huebner, E. S., \& Valois, R. F. (2003). Preliminary validation of the brief multidimensional student's life satisfaction scale. Social Indicators Research, 61, 121-145. doi:10.1007/s11205-005-5395-9.

Seligson, J. L., Huebner, E. S., \& Valois, R. F. (2005). An investigation of a brief life satisfaction scale with elementary school children. Social Indicators Research, 73(3), 355-374. doi:10.1007/s11205-004-2011-3.

Singh, K., Ruch, W., \& Junnarkar, M. (2015). Effect of the demographic variables and psychometric properties of the personal well-being index for school children in India. Child Indicators Research, 8 , 571-585. doi:10.1007/s12187-014-9264-4.

Suldo, S. M., \& Huebner, E. S. (2006). Is extremely high life satisfaction during adolescence advantageous? Social Indicators Research, 78, 179-203. doi:10.1007/s11205-005-8208-2.

Suldo, S. M., Minch, D. R., \& Hearon, B. V. (2015). Adolescent life satisfaction and personality characteristics: investigating relationships using a five factor model. Journal of Happiness Studies, 16, 965-983. doi:10.1007/s10902-014-9544-1.

Tomyn, A. J., \& Cummins, R. A. (2011a). Subjective wellbeing and homeostatically protected mood: theory validation with adolescents. Journal of Happiness Studies, 12, 897-914. doi:10.1007/s10902-01-9235-5.

Tomyn, A. J., \& Cummins, R. A. (2011b). The subjective wellbeing of Australian high-school students: validating the personal well-being index-school children. Social Indicators Research, 101(3), 405-418. doi:10.1007/s11205-010-9668-6.

Tomyn, A. J., Cummins, R., \& Norrish, J. M. (2015). The subjective wellbeing of "at risk" indigenous and non-indigenous Australian adolescents. Journal of Happiness Studies, 16, 813-837. doi:10.1007/s10902014-9535-2.

Ullman, C., \& Tatar, M. (2001). Psychological adjustment among Israeli adolescents immigrants: a report on life satisfaction, self-concept, and self-esteem. Journal of Youth and Adolescence, 30, 449-464.

Valois, R. F., Zullig, K. J., Huebner, E. S., \& Drane, J. W. (2009). Youth developmental assets and perceived life satisfaction : is there a relationship? Applied Research in Quality of Life, 4, 315-331. doi:10.1007/ s11482-009-9083-9.

Vaux, A., Phillips, J., Holly, L., Thomson, B., Williams, D., \& Stewart, D. (1986). The Social Support Appraisals (SS-A) scale: studies of reliability and validity. American Journal of Community Psychology, 14(2), 195-219.

Weber, M., \& Huebner, E. S. (2015). Early adolescents' personality and life satisfaction: a closer look at global vs. domain-specific satisfaction. Personality and Individual Differences, 83, 31-36. doi:10.1016/j.paid. 2015.03.042.

Weber, M., Ruch, W., Littman-Ovadia, H., Lavy, S., \& Gai, O. (2013). Relationships among higher-order strengths factors, subjective well-being, and general self-efficacy - the case of Israeli adolescents. Personality and Individual Differences, 55, 322-327. doi:10.1016/j.paid.2013.03.006.

Yik, M., Russell, J. A., \& Steiger, J. H. (2011). A 12-point circumplex structure of core affect. Emotion, 11, 705-731. doi:10.1037/a0023980. 